\title{
Frequency and spectrum of chlorophyll mutations in greengram [Vigna radiata (L.) Wilczek]
}

\author{
N. VAIRAM, S.M. IBRAHIM AND C.VANNIARAJAN \\ Department of Plant Breeding and Genetics, Agricultural College and Research Institute (T.N.A.U.), MADURAI \\ (T.N.) INDIA \\ Email : vairamagri@gmail.com
}

\begin{abstract}
Greengram [Vigna radiata (L.) Wilczek], popularly known as mungbean, is third most important pulse crop of India. Mungbean is a cheap source of dietary protein for the poor, with high levels of folate and iron compared with many other legumes. Variability is low available in mungbean and hence, to replace conventional breeding, mutation breeding has gained its momentum. Induced mutagenesis thus seems to be an ideal methodology for the induction of desirable genetic variability. Chlorophyll mutations, an important index in the estimation of induced genetic changes in mutagen treated population are most widely employed for assessing the potentialities of mutagens in creating genetic variability. An investigation was carried out in two mungbean genotypes $\mathrm{CO}(\mathrm{Gg}) 7$ and $\mathrm{NM} 65$ treated by two mutagens viz., gamma rays and ethyl methane sulphonate. A wide range of chlorophyll mutations was observed and scored in $\mathrm{M}_{2}$ generation. The highest frequency rate was noted at 300 Gray and $10 \mathrm{mM}$ on $\mathrm{M}_{1}$ plant basis and $\mathrm{M}_{2}$ seedling basis in both the genotypes. The mutant chlorina and xantha occurred in all the treatments of gamma rays and EMS at higher proportions.
\end{abstract}

Key words : Greengram, Chlorophyll mutation, EMS, Gamma rays, Variability

How to cite this paper : Vairam, N., Ibrahim, S.M. and Vanniarajan, C. (2014). Frequency and spectrum of chlorophyll mutations in greengram [Vigna radiata (L.) Wilczek]. Asian J. Bio. Sci., 9 (2) : 204-207. 